\title{
A Conceptual Study of the Strategic Role of Gastronomy in Tourism Destinations
}

\section{Faruk Seyitoğlu}

Faculty of Tourism, Mardin Artuklu University, Turkey; e-mail: seyitoglu.f@gmail.com

\section{Stanislav Ivanov}

Professor, Varna University of Management, 13A Oborishte Str., 9000 Varna, Bulgaria, tel: +359 52 300 680, e-mail: stanislav.ivanov@ vumk.eu .Personal website: http://www.stanislavivanov.com

\begin{abstract}
The present study aims to discuss the strategic role of gastronomy in destinations. The study utilised the three theoretical foundations of strategic management, namely Resource-Based View (RBV), Emergent Strategy (ES) and Positioning Strategy (PS). Several concepts from the field of gastronomy were used, such as gastronomic identity, tourist behaviours (motivation, experience, consumption), a sense of place, and food image. Utilizing this multi-disciplinary literature, the present study provides an integrative review of developing a model explaining the strategic role of gastronomy in tourism destinations. The predictions of the model are supported by the conceptual and empirical findings of earlier studies.
\end{abstract}

Keywords: Gastronomy, strategy, destination competitiveness, resource-based view, emergent strategy, positioning strategy

\section{Introduction}

It is generally accepted that there is a strong relationship between tourism and gastronomy (Rand et al., 2003; Chaney \& Ryan, 2012; Leng \& Badarulzaman, 2014; Chang \& Mak, 2018), which destinations can use to gain a competitive advantage (Horng \& Tsai, 2012; Mascarenhas \& Gandara, 2015). Although there are studies which are benefiting strategic approaches such as resource-based view (Lee \& King, 2006; Massukado-Nakatani \& Teixeira, 2009; De Carlo \& Dubini, 2010; Evans, 2016; Alonso, 2017b; Horng \&Tsai, 2012; Alonso \& Bressan, 2016; Alonso, 2017a), emergent strategy (Bourlakis \& Bourlakis, 2001; Ottenbacher \& Harrington, 2013; Aydın, 2019) and positioning strategy(Chen \& Uysal 2002; Claveria \& Poluzzi, 2017; Evren \& Kozak, 2018; Frochot, 2003; Gianezini, Alves, Techemayer \& Révillion, 2012; Klinger, Silveira-Martins, de Castro \& Rosetto, 2019) in hospitality, tourism, and gastronomy literature, there is not much dealt with the question of what is the strategic role of gastronomy in tourism destinations. Especially the study which has benefited these three strategic approaches (resource-based view, emergent strategy and positioning strategy) to investigate the strategic role of gastronomy in destinations remains underexplored in the literature. Therefore, this study aims to develop a model to address this problem by drawing on the discipline of strategic management.

In an increasingly competitive market, the search for unique attributes that can provide a destination with a competitive advantage is key. A popular and promising destination attribute that can impact its competitiveness is gastronomy. Thus, the integration of local gastronomy and tourism is a critical component of contemporary destination marketing strategies. From an academic perspective, three major questions arise when a strategic approach is adapted to a particular case; what is the (i) source, (ii) process, and (iii) form of the strategy.

The current study aims to respond to the mentioned questions by offering a conceptual model that relies on two fields of study: the first is the relatively well-established discipline of strategic management and the second is the growing field of gastronomy-tourism relations. Three theoretical foundations of 
strategic management, namely the Resource-Based View (RBV) (Barney, 1991), Emergent Strategy (ES) (Mintzberg, 1978) and Positioning Strategy (PS) (Porter, 1980), were employed to explain how destinations can gain a competitive edge in the process of turning resources into concrete strategies. On the other hand, previous studies on the relationship between gastronomy and tourism (Hjalager, 2004; Kivela \& Crotts, 2006; Hall \& Mitchell, 2007; Karim \& Chi, 2010; Jiménez Beltrán, López-Guzmán \& SantaCruz, 2016; Chang \& Mak, 2018; Agyeiwaah, Otoo, Suntikul, \& Huang, 2019; Widjaja, Jokom, Kristanti $\&$ Wijaya, 2020) have been drawn upon to understand how tourists experience local gastronomy and how they perceive destinations via their gastronomical assets, regarding fundamental concepts such as gastronomic identity, tourist behaviours (motivation, experience, consumption), a sense of place, and food image. Consequently, the model proposed by the current study draws connections between the concepts in these two fields to explain the role of gastronomy in destinations.

According to the aim of the present study, The structure of the paper starts with the three strategic approaches (resource-based view, emergent strategy, and positioning strategy) and their relationship with hospitality and tourism literature including gastronomy will be explained. Moreover, the review of gastronomy concepts follows this. After presenting the literature of strategic approaches and gastronomy, section 3 provides the conceptual model and the predictions that are supported by the conceptual and empirical findings of conducted studies. Finally, the conclusion section which includes the summary of the presented model and its implication is given in the paper.

\section{Literature Review}

\subsection{Three Theoretical Foundations of Strategic Management and their Relationship with Hospitality and Tourism}

\section{Resource-Based View}

The resource-based view assumes that organizations can gain a sustainable competitive advantage by utilising resources that differ from those of their competitors (Grant, 1991; Barney, 1991). A considerable number of studies have discussed and adopted the resource-based approach (Barney, 2001; Peteraf, 1993; Wernerfelt, 1995; Barney, Wright \& Ketchen, 2001; Acedo, Barroso \& Galan, 2006; Maurer, Bansal \& Crossan, 2011). RBV consist of unique resources and capabilities of firms that form their strategical performance. According to the RBV, any difference in a businesses' performance is based mostly on its unique resources and capabilities, not from the structural characteristics of the relevant industry (Lee \& King, 2006). The resources of firms may be physical capital resources, human capital resources, organizational capital resources. This means that there are also intangible resources of businesses such as values, knowledge, and beliefs (Rusko, Merenheimo \& Minni Haanpää, 2013). In line with Barney's (1991) research, Grant (1991) proposed a framework consisting of a five-step process based on the beliefs of the resource-based approach: (i) identifying and classifying resources, (ii) identifying capabilities, (iii) assessing the potential competitive advantage and appropriability of the organisation, (iv) selecting strategies that will capitalise on the capabilities and resources of the organisation in the pursuit of external opportunities, (v) the identification of resource gaps and the upgrading of resources (Grant, 1991). Furthermore, Barney (1991) states that the firm resources must be characterised by attributes such as valuable, rare, inimitable and non-substitutable in terms of sustainable competitive advantage.

RBV has been widely utilized in the hospitality and tourism literature (Lee \& King, 2006; Massukado-Nakatani \& Teixeira, 2009; Andreu, Claver \& Quer, 2010; De Carlo \& Dubini, 2010; Peters, Siller \& Matzler, 2011; Rusko, Merenheimo \& Haanpää, 2013; Evans, 2016; Alonso, 2017b) including in the context of gastronomy tourism (Horng \&Tsai, 2012; Alonso \& Bressan, 2016; Alonso, 2017a; Alonso, Kok \& O'Brien, 2018). For instance, the study of Lee and King (2006), proposes a conceptual model to 
find out the components determining the competitiveness of the hot springs tourism sector in Taiwan via benefiting the RBV and the theories of industry organization (IO). Moreover, the exploratory study of Alonso (2017b) investigates the components of tourism development in Uruguay adopting the RBV view of businesses based on the perspectives of tourism stakeholders. Peters, Siller \& Matzler (2011) investigate the difference between RBV and market-based view (MBV) of stakeholders and the effects of these approaches on their perception related to cultural tourism development.

From the studies which integrate RBV and gastronomy, Alonso (2017a) aimed to reveal the most significant resources, and issues among Spain's Cava wineries through the lens of the resource-based view of the firms. The attributes related to the RBV, such as valuable, rare, imperfect imitable resources and nonsubstitutability emerged in the study (Alonso, 2017a). Another related study (Alonso \& Kok, 2018) suggests a framework based on the RBV and the dynamic capabilities approach for understanding a region's attractiveness from an international perspective. Furthermore, Alonso and Bressan (2016) aimed to adopt the resource-based view (RBV) of the firm to explore the most important resources among micro and small firms operating in Italy's wine industry. Alonso, Kok \& O'Brien (2018) have benefited from RBV to examine the potential of culinary tourism from the perspective of restaurant operators in Lima- Peru and develop a framework of culinary tourism.

\section{Emergent Strategy}

Mintzberg (1978) defines strategy as a pattern in the form of current decisions, countering the idea that a strategy is simply a plan. By distinguishing between two aspects of strategy, namely intended and realized, Mintzberg claims that the combination of both aspects can lead to three different situations. Thus, intended strategies are called 'deliberate strategies' when they are realized, and 'unrealized strategies' when they fail, regardless of the reason. It is emphasised that in order to bring about a deliberate strategy, three conditions must be met: (i) the strategic intentions must be exact and fully expressed, (ii) all actors in the organization must be well informed about the strategy, and (iii) the strategy must be protected from the effects of external forces (i.e. environmental factors must be completely under control). However, it has also been stated that these conditions do not exist, and thus a deliberate strategy cannot be implemented perfectly. Emergent strategies, on the other hand, are unplanned strategies that are not intended (Kopmann et al., 2017); a perfectly emergent strategy must be ordered in the absence of intention.

Although various studies (Mariani, 2007; Mirabeau \& Maguire, 2014; McDermott \& O'Connor, 2002; Downs, Durant \& Carr, 2003; Bodwell \& Chermack, 2010) related to emergent strategy approach conducted in the literature, not many studies (Bourlakis \& Bourlakis, 2001; Ottenbacher \& Harrington, 2013; Aydin, 2019) related to this approach exist in the hospitality literature including gastronomy. For example, Bourlakis and Bourlakis (2001) attempted to find out which strategic approach is followed by businesses that operate in the Greek food multiple retail sectors. The aim of a case study (Ottenbacher $\&$ Harrington, 2013) was to explore the key issues in the strategic process of a culinary tourism campaign in Germany. Another study (Aydin, 2019) aimed to indicate the strategy that was benefited regarding the process of integrating gastronomy and tourism. The findings show that no clear strategy which would be useful for gastronomy within the framework of tourism in Cappadocia found.

\section{Positioning Strategy}

Since it is found to be a component of competitive advantage (Porter, 1980), market positioning strategy considered as one of the most significant elements of management in terms of having long term advantages for businesses to be successful in the market (Rodríguez-Molina, Frías-Jamilena, Del BarrioGarcía \& Castañeda-García, 2019). As the core element of positioning, differentiation can be ensured for 
one or more of the qualities of products, such as durability, technical features, design differences, or customer services (Porter, 1980). Businesses that adopt a differentiation strategy expect customers to pay the price difference by differentiating between the features of a product. On the other hand, customers expect the products they choose to meet their expectations and are willing to pay a higher price for this (Porter, 1980; 1996).

Differentiation is generally linked to the development of services and products that offer inimitable attributes that are valued by customers and that provide better value than their competitors (Porter, 1985). Porter (1980) identifies the following sources of differentiation: location, product features, product mix, reputation, association between functions, and links with other businesses. Barney (2002), who has examined differentiation-based competitive advantage from a source-based perspective, demonstrates, based on observations of firms' behaviours, that there are five characteristics of differentiation: product complexity, product customization, different distribution channels, an emphasis on consumer marketing, and services and support. Achieving such differentiation is dependent on managers' efforts and creativity (Barney, 2002). It is clear from the related literature that for a differentiation strategy to be successful, research and development (R\&D) and advertising are considered as a basic requirement (Porter, 1980; Barney \& Hesterley, 2006). While R\&D will lead to innovation and uniqueness, promotion contributes to the firm's value (Gao \& Hafsi, 2018). Moreover, it is emphasized that the main aim of product differentiation is to build up a position that is seen as unique and creates a sense of value for potential customers (Shoemaker et al., 2007).

Although the positioning strategy was initially applied to products, due to its popularity and applicability it is considered as an important strategic approach for other areas including hospitality and tourism ( $\mathrm{Li}$, Cheng, Kim \& $\mathrm{Li}, 2015)$. Regarding hospitality and tourism literature, the destination positioning has been mentioned by various studies especially in terms of comparing the competitiveness of destinations (Crompton, Fakeye \& Lue 1992; Botha, Crompton and Kim, 1999; Uysal, Chen, and Williams 2000; Chen \& Uysal 2002; Li et al., 2015; Claveria \& Poluzzi, 2017; Evren \& Kozak, 2018). Moreover, there are also studies related to positioning strategy in the context of image (Gallarza, Gil, \& Garcia, 2002) and brand (Rodríguez-Molina et al., 2019) in the hospitality and tourism literature.

The main point of positioning in the context of tourism destination marketing is to identify the critical characteristics that travellers had in mind and reinforcing them (Chen \& Uysal 2002). As there is a tough competition between tourism destinations to attract tourists, positioning has become a crucial strategy (Rojas-Mendez \& Hine, 2017). Because each destination has various attributes that have the potential to attract tourists (Kim, Guo \& Agrusa, 2005). Therefore, for effective positioning, the differentiated characteristics which distinguish one destination from others would be attractive attributes for potential travellers (Crompton et al., 1992). These characteristics should be promoted properly as they are critical elements of marketing strategies to position the destination (Rodríguez-Molina et al., 2019).

Considering the gastronomy and food area, the studies which are related to strategic positioning have been conducted in the existing literature (Frochot, 2003; Gianezini, Alves, Techemayer \& Révillion, 2012; Klinger et al., 2019). For instance, Gianezini et al., (2012) investigated food industries that adopt strategies of differentiation and indicated that organizations that achieve success are focused on differentiation of packaging, brand, and price (Klinger et al., 2019). The study of Frochot (2003) aims to identify the different food images that may be used by tourism advertisers in their promotional material. Moreover, it is also aimed to find out how different food images can be used for destinations' positioning strategies. A recent study (Klinger et al., 2019) was aimed to investigate the influence of managers' strategic orientation on decision-making related to differentiation and the impact of these two factors on the performance of the wine businesses in Brazil. 
As it is understood from the above-mentioned literature three strategic approaches have been widely used in strategic management, hospitality, and tourism literature. Although these approaches separately implemented in hospitality and tourism literature, no study has benefited from these approaches together found in the current literature. Especially regarding the use of gastronomy in destinations, it may be useful to reveal a conceptual strategic model benefiting from these three approaches.

\subsection{Review of the Relevant Literature on Gastronomy}

Unlike some other travel activities, eating is essential for visitors to a destination as it is a primary need (Kumar, 2019). Thus, travellers always have a budget for food and beverages. In this respect, tourists visiting a destination have a high likelihood of encountering the local cuisine or local food of that destination. Moreover, as it is the outcome of social, natural and cultural factors of regions and reflects the local culture in the form of unique gastronomic values (Gordin, Trabskaya \& Zelenskaya, 2016), gastronomy is a significant factor that is portraying the culture of destinations (Kim, Eves \& Scarles, 2009; Hillel, Belhassen \& Shani, 2013). Thus, this aspect of gastronomy is attracting tourists who are motivated to learn about different cultures through local food and beverages (Kumar, 2019). It is stated that local food is a crucial attraction for tourists and a significant factor for the tourist experience (Henderson, 2009).

As an element of cultural tourism, gastronomy offers new tastes and flavours of local cultures which are also providing learning opportunities for visitors (Widjaja et al., 2020). Tourists having a strong desire for local food may search for novel gastronomic experiences. Moreover, it is indicated that tourists experiencing local food likely to have a memorable experience which may positively affect their satisfaction, revisit intention and word of mouth (Ignatov \& Smith, 2006; Björk \& Kauppinen-Räisänen, 2014). Furthermore, tourism destinations may have a strong image that includes their unique cuisine and cultural values (Hall and Mitchell, 2007).

Additionally, via providing destination's cultural heritage, gastronomy tourism has a significant role in satisfying and leading memorable experiences to travellers (Hjalager and Richards, 2002; BalderasCejudo, Patterson \& Leeson, 2019). Thus, providing a memorable experience will result in a sustainable competitive advantage (Widjaja et al., 2020). This attractive potential of gastronomy tourism has become an important strategic element in terms of the tourism and hospitality sector. Therefore, tourism destinations have increasingly using their gastronomic resources to differentiate them from their competitors (Kumar, 2019).

\section{Gastronomic Identity}

Gastronomic identity emerges where two factors meet, namely the environment (climate and geography) and culture (religion, history, ethnic diversity, traditions, values, and beliefs). It encompasses the flavours, recipes, materials, techniques, and manners that belong to a specific region (Harrington, 2005). To create and provide a gastronomic identity, Fox (2007) suggests approaches such as differentiation, aestheticization, authentication, symbolization, and rejuvenation. This is considered a beneficial framework for presenting a destination's gastronomic identity (Chang \& Mak, 2018). Differentiation means using gastronomic products to create or emphasise the cultural difference. Aestheticization, meanwhile, involves offering gastronomic products in a way that engages tourists' minds and taste buds and interacts with their lifestyles, personal feelings, and social status. The third approach, authentication, should be aimed at fulfilling the authenticity needs of tourists. Symbolization means to culturally attribute values to ingredients, meals, menus, and gastronomic processes typical to the destination; this helps in the creation of gastronomic symbols. The final approach, rejuvenation, refers to the reactivation of local culinary customs or heritage by returning to traditional methods of food preparation (Chang \& Mak, 2018). 
It is indicated that the existence of a gastronomic identity may affect both on creating a sense of place and bringing together different cultures (Harrington \& Ottenbacher, 2010). Tourists can participate in authentic local food activities, and these experiences then have the potential to spread through word-ofmouth (Andersson \& Mossberg, 2017). Capital theory supports this by emphasizing that consumers' experiences and understanding of cultural practices can come up in conversations with others (Shenoy, 2005). In summary, given that a great many people want to experience authentic food (Sims, 2009), a gastronomic identity is considered a unique source for tourism destinations.

\section{Tourist Behaviours and Motivations Related to Gastronomy}

Gastronomic identity and gastronomic tourism products only account for the supply side of this issue. There is also the demand side and from this perspective, tourist behaviours and tourist motivations that are associated with gastronomy are important issues. Accordingly, tourist typologies that relate to these subjects are significant and need to be examined. For example, Fields (2002) divides tourists' food-related motivations into four groups: cultural, interpersonal, physical, and status and prestige. Kim et al. (2009) describe authentic experience and learning or knowledge as subsets of cultural motivation. In their study, motivational factors such as escape from the routine, an exciting experience, health concerns, an authentic experience, togetherness, gaining knowledge, the physical environment, prestige, and sensory appeal are identified as aspects of local food consumption.

According to the gastronomy tourist typology suggested by Hjalager (2002), tourists can be categorised as recreational, diversionary, experiential and existential in terms of their food preferences. First, it is argued that diversionary and recreational travellers prefer familiar food; consequently, their motivations towards local foodstuffs are weak. Moreover, food is not a peak experience for these types of tourists. On the other hand, existential and experiential tourists have stronger motivations towards food. For them, food is seen as a peak experience that they may gain whilst on their travels. Another gastronomy tourist typology, suggested by Boyne et al. (2003), is based on tourists' information searches. In this typology, for Type 1 tourists, food is an important part of their total touristic experience. They search for food-related information when travelling to a destination. Type 2 tourists, on the other hand, are not active searchers when it comes to food but when they encounter food-related information, they are sometimes interested in it. Type 3 and 4 tourists, meanwhile, do not search for food-related information at all. Nevertheless, Type 3 tourists are sometimes passive observers and may take part in food-related activities when they encounter them.

In terms of tourists' perspectives, it can be concluded from these classifications that the significance of food experiences as part of the total tourist experience depends on tourists' interest in foodstuffs and local gastronomy. Quan and Wang (2004) explained this issue in their study using a conceptual model. They emphasized that food is the main component of the tourist experience when it is also the main motivational factor. In such cases, the consumption of local food can provide memorable and enjoyable experiences for tourists.

The significance of gastronomy as a motivation for tourists is obvious in many tourism destinations (Agyeiwaah, Otoo, Suntikul \& Huang, 2019). Further, in many destinations such as Hong Kong, Australia, Canada, South Africa and France the desire for gastronomy is considered more important than other attractions (Agyeiwaah et al., 2019). Moreover, studies (Quan \& Wang, 2004; Alonso, 2010; Hjalager \& Corigliano, 2000) have stressed that gastronomy tourism may enable positive destination experience and image.

According to these concepts, definitions and explanations, it can be concluded that by integrating strategy and gastronomy, tourism destinations may obtain a competitive advantage. Therefore, with the help of this review of the extant literature, a conceptual model is proposed in the present study. This model 
explains the role of gastronomy in destination competitiveness through making connections between concepts from the disciplines of strategic management and gastronomy.

\section{The Proposed Conceptual Model: Strategic Role of Gastronomy in Destinations}

To understand the role of gastronomy in gaining a competitive advantage for a destination, there is a need to evaluate whether gastronomy is a strategic resource for a destination; if gastronomy is a strategic resource, what kind of process will help it form a strategy? The conceptual model presented in Figure 1 is based on the concepts and theories in the relevant literature (strategy and gastronomy) and is a response to this need. According to the model, a gastronomic identity is a strategic resource for a destination. A strategy that sets a destination apart from its competitors could be formed through the presentation of gastronomic tourism products that are created using this resource (gastronomic identity). This strategy is at least initially the result of an organic process rather than a planned approach. However, in time, the process can be transformed into a deliberate strategy when it is realized that a strategy based on gastronomy is already developing. Destination managers or stakeholders can therefore engage in planned actions to develop and implement a differentiation strategy based on gastronomy.
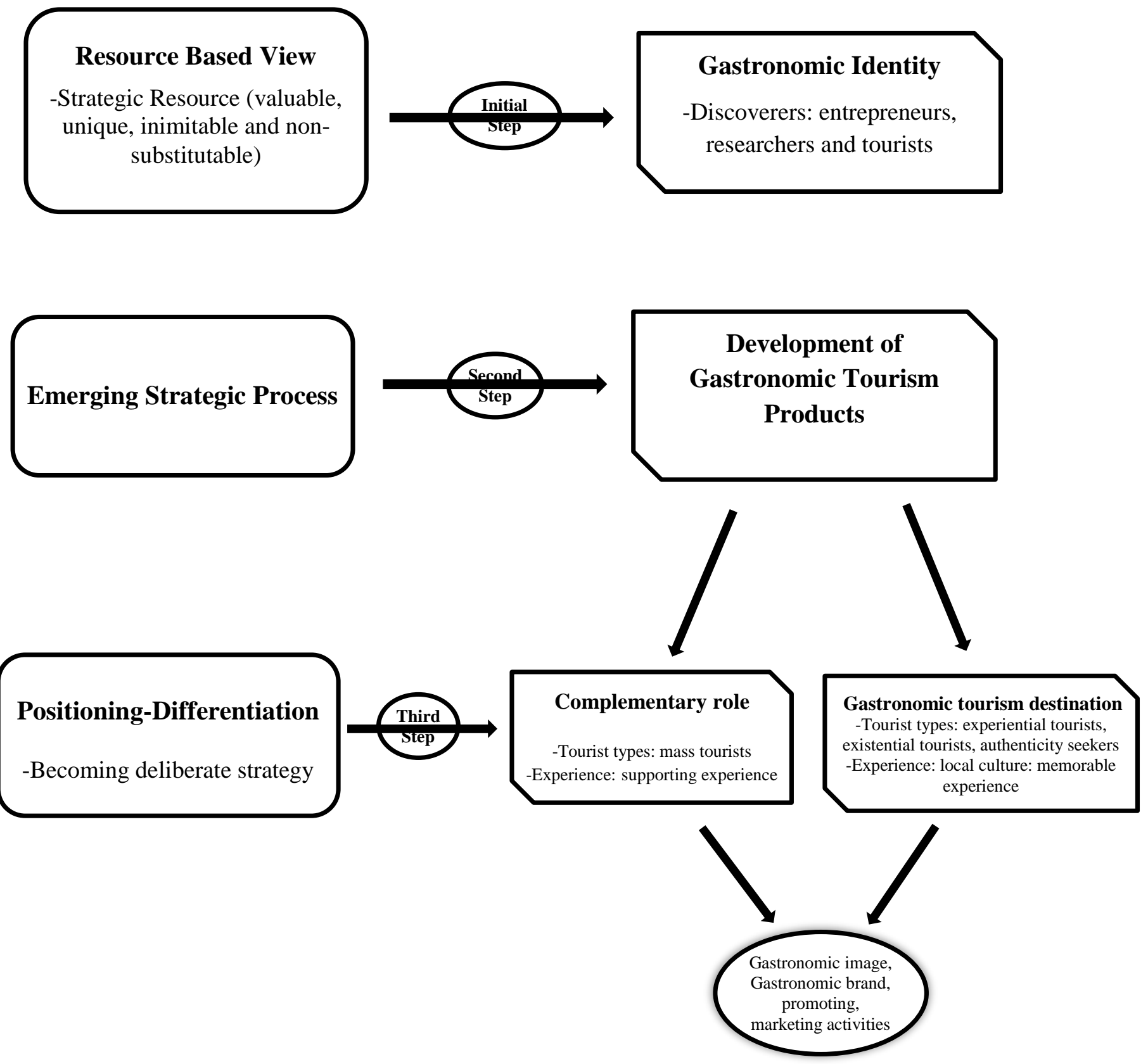

Figure 1. The conceptual model of the strategic role of gastronomy in destinations 


\section{Resource based view (strategic resource-gastronomic identity)}

According to the RBV, to be considered strategic, resources need to be valuable, unique, inimitable, and non-substitutable (Barney, 1991). Only a strategic resource that has all of these qualities can help achieve a sustainable competitive advantage. Gastronomic identity is accepted as an original resource of destinations that is valuable, rare, inimitable, and non-substitutable (Harrington \& Ottenbacher, 2010). Uzut's (2016) empirical findings, from a study carried out with tourism stakeholders in Istanbul, support this view.

The gastronomic identity of a destination is the main element influencing tourists who have a strong motivation for gastronomy (Kim et al., 2009) and those whose food-related consumption plays an important role in tourism experiences (Quan \& Wang, 2004). However, a gastronomic identity cannot be directly experienced by tourists because of its intangible components and the limited availability of existing tangible components. Therefore, gastronomic tourism products that are produced based on a gastronomic identity are needed by destinations (Nebioğlu, 2016). Gastronomic tourism products may include local food and beverages, innovative recipes that use local ingredients, agricultural practices, regional production techniques, local restaurants, festivals, food or wine routes, farms, and food-related museums, etc. (Smith \& Xiao, 2008). However, a strategic process is required for the development of these products and their presentation to relevant tourist markets. One of the most important stages of this process is the discovery of a gastronomic identity.

Horng and Tsai (2012), in their study of the relationship between gastronomy and destination competitiveness, identified the determination of gastronomic tourism resources and their effective use as the first key factor in the success of a destination. The actors in a destination who may discover a gastronomic identity include tourists, entrepreneurs, and researchers. Tourists traveling for a unique gastronomic experience may be the main explorers of the gastronomic values of a destination (Hjalager, 2004). On the other hand, researchers working on the gastronomic values of a region may also be effective in the discovery of a gastronomic identity. Meanwhile, entrepreneurs can realize the value of the unique gastronomy of a destination by recognizing the interest of tourists and researchers, enabling them to foresee the potential economic benefits of a gastronomic identity.

\section{Emergent strategic process-development of gastronomic tourism products}

The process of developing gastronomic tourism products may be considered as an autonomous strategic initiative (Mirabeau \& Maguire, 2014). According to Mirabeau and Maguire (2014), in a business, entrepreneurs try to generate solutions or innovations by evaluating the opportunities they see; this may also help with the development of a strategy for the business as a pattern emerges over time. A similar process can also be observed at the destination level, with products based on a gastronomic identity, whose value has been discovered by discoverers (entrepreneurs, researchers or tourists) playing a key role in the development of this process. At this stage, discoverers will not only appreciate the value of a gastronomic identity but also develop gastronomic tourism products and implement cooperation opportunities with stakeholders. In addition, they will begin to engage in efforts such as the production and marketing of gastronomic tourism products. Although these efforts may be deliberate, at the destination level, it is apparent that this process is not actually a deliberate strategic planning approach. Rather, as Mintzberg (1978) clearly states, it is a strategic process is known as an "emergent strategy" which is initially unintended and occurs as a result of decisions and actions taken and lessons subsequently learned.

The findings of the conceptual and empirical studies in the literature support this view, that concerning gastronomy, an emergent strategic process is more likely to happen at the destination level. For 
example, Hjalager (2002) conceptualized the development of gastronomic tourism in four stages, hierarchically listed as local, horizontal, vertical and diagonal. In the first stage, the "local stage", gastronomic products are introduced into promotional materials, while the improvement and protection of the quality of these products is the next stage, known as the "horizontal stage". In the third, "vertical stage", gastronomic products are combined with other tourism products, and other new products are developed. The last stage, "diagonal development", refers to the possibility of marketing gastronomic knowledge. The whole process begins with tourists' interest in local gastronomic products and continues as increasingly complex relationships between entrepreneurs are developed. This conceptual definition points to a pattern that is shaped by decisions and actions taken in response to developments at each stage (mostly tourist demand and competition), rather than by deliberate actions based on a long-term plan. More concrete evidence that this process is an emerging strategic process rather than a planned approach can be found in empirical studies. Ottenbacher and Harrington (2013) support this statement by providing a qualitative study of the development of gastronomy tourism at a destination in Germany. The results of the study show that, because of, for example, the absence of a deliberate strategy at the beginning and a lack of stakeholder management and leadership at the destination, a planned strategy could not be implemented; rather, a strategy emerged with initiatives taken to take advantage of the potential benefits of gastronomy for the destination. Similar findings were obtained by a study of tourism stakeholders in Cappadocia (Aydin, 2019). According to this research, local gastronomic tourism products such as local restaurants and wine tasting have emerged in response to tourist demand through the individual initiatives of local entrepreneurs following the predicted gastronomic potential of the region. The results also show that an emergent strategy is more convenient for Cappadocia because of the lack of a clear strategy (Aydin, 2019).

\section{Positioning strategy-differentiation (deliberate strategy)-complementary role/gastronomic tourism destination}

It should be emphasised that it is important for destination managers to position their destinations to attract potential visitors. For tourism destinations, positioning is a process which starts with determining the rivals and creating or offering a unique feature that is not found in other destinations in tourists' mind (Kim, Guo \& Agrusa, 2005). Unique attributes of destinations are considered as the most significant components for effective positioning that make difference from rivals (Rodríguez-Molina et al., 2019). It is stated that a unique strategic position is an indicator of the decision making of consumers and encourages the implementation of strategies. Strategic position based on unique features leads to a differentiated value which is essential for consumers and advantages in terms of competition with rivals (Klinger et al., 2019). With the help of positioning strategy, a destination may differentiate its products or services in comparison with its rivals, to provide a unique experience (Klinger et al., 2019).

Providing a unique gastronomic identity and thus generate a destination image will help to attract the attention of target visitors in tourism destinations. Thus, the destination will be able to use its gastronomic identity as a strategic resource to achieve a differentiated position in the tourism market. In fact, the strategic role of gastronomy in terms of the destination is embodied at this stage. Accordingly, gastronomy can either play a complementary role or it can transform the destination into a gastronomic tourism destination. In the case of the former, while gastronomy is not the main reason for tourists visit the destination, it may nevertheless influence the selection of the destination, the pleasure of the tourism experience, and tourists' revisit intentions. On the other hand, when a destination becomes a gastronomic destination, experiencing local food and culture may be the main purpose of traveling to the destination. However, in both cases, the destination differentiates itself with the unique features of its gastronomy. A study that supports this view examined the use of food in promotional material at two different destinations, Hong Kong and Turkey (Okumus et al., 2007). The study found that food is seen as the main component 
of destination competitiveness in Hong Kong, and the destination positions itself as an international destination for gastronomy. On the other hand, although Turkey has a unique and rich local cuisine, it makes less use of food in its marketing. Thus, gastronomy is seen as a complementary component.

As predicted by the strategic management literature, an emerging strategy may become a deliberate strategy over time (Mintzberg, 1985). The relationship between gastronomy and destination competitiveness can be seen in geographical marking and marketing studies. Geographical marking aims to highlight and preserve the uniqueness of local gastronomic products and show that destination management understands the value of gastronomy for tourism and the need for actions to be taken in this respect. Whether it is a complementary or main component in destination marketing, the use of gastronomy should be conscious.

Both ways may require different marketing approaches for tourist groups with different gastronomic motivations. For example, while gastronomy can be positioned as a complementary component in destination marketing for mass tourists as supporting experience, the destination can also be marketed as a gastronomic destination for gastronomy tourists as a memorable experience. The second option (gastronomic tourism destination) can be explained using Hjalager's typology (2004) of experiential and existentialist tourists and Özdemir and Seyitoğlu's (2017) typology of authenticity seekers with high motivation for experiencing local food and beverages. These types of tourists will have a different perspective on destinations with gastronomic tourism products based on a gastronomic identity. Moreover, memorable gastronomic experiences in such destinations will help tourists develop an emotional connection with the destination and create a sense of place (Tsai, 2016).

A memorable experience is a multi-dimensional term that includes elements such as locality, relaxation, hedonism, refreshment, adverse feelings, happiness, meaningfulness, knowledge, novelty, unexpected happenings, involvement, and participation. In addition, these experiences are usually unforgettable after the event(s) (Kim, Ritchie, \& McCormick, 2012). Interactions with locals are considered the main element of the tourist experience (Coudounaris \& Sthapit, 2017). Therefore, experiencing local culture is an important component of the memorable moment (Morgan and $\mathrm{Xu}, 2009$ ). Moreover, the memorable experience has been found to have a significant relationship with satisfaction and positive revisit intentions (Oh et al., 2007).

Since foodstuff play a vital role in travel, tourists may want to enjoy and not forget their experiences of food in tourism destinations (Kivela \& Crotts, 2006). It is argued that food consumption in tourism destinations usually connects people with their past (Vignolles \& Paul-Emmanuel, 2014). This is empirically supported in Chandralal and Valenzuela's (2013) study, which shows that participants' memories are strongly linked with local food experiences in foreign destinations. Moreover, authenticity increases the memorability of the travel experience (Sthapit, 2017). As has already been stated, with the help of memorable experiences, tourists may develop an emotional connection to a destination, which then leads to a sense of place (Tsai, 2016).

Consequently, by providing a connection with local culture (Hjalager \& Richards, 2002), gastronomy may be the reason why tourists have memorable travel experiences. Furthermore, tourism destinations may have a strong image that includes their unique cuisine and cultural values (Hall \& Mitchell, 2007). The related literature shows that it is possible to create a positive food image to develop and strengthen a sense of place, as tourists identify a certain destination with a certain gastronomic identity (Karim \& Chi 2010). Thus, tourists will tend towards choosing to visit destinations that have a sense of place and a food image (Chi et al., 2013). On the other hand, creating a positive food image may be possible with effective marketing techniques (Rand et al., 2003). First, a good knowledge of local cuisine and local culture is needed to generate a strong image (Horng \& Tsai, 2010). Reflections on these views in practice are seen more clearly in studies on the promotional materials of destinations. Destinations can provide 
information on local food culture, local restaurants, recipes and menus in their promotional materials (Beer et al., 2002). Thus, it is assumed that it will be possible to influence the destination selection decisions of tourists through promotional materials and websites. The content of government websites in particular is seen as crucial for the promotion of destinations' local food as they can help shape the culinary image of a destination (Horng \& Tsai, 2010). On the other hand, destination branding that is closely related to the image, has been identified as a way to communicate a destinations' unique identity by differentiating destinations from their rivals (Rojas-Mendez \& Hine, 2017). Furthermore, destination branding contributes the differential destination image which has a key role in creation of destination positioning (Pike \& Ryan, 2004).

The importance of promotional materials for creating a destination's food image is also highlighted in the literature. For instance, Frochot's study (2003) of the promotional materials of 19 destinations in France revealed how local cuisine and gastronomy items (e.g. cheese, restaurant dishes, local products, and wine) were used as part of France's international tourism promotion strategy. Another study (Okumus et al., 2013) examined the promotional materials of the four Caribbean islands, and found that the extent of the representation of food in both text and images vary depending on the marketing strategy adopted.

In summary, the conceptual model describes a strategic process that starts with a gastronomic identity as a strategic resource through to the development of gastronomic tourism products. In this process, gastronomy, which takes the form of a type of differentiation strategy with the potential to be turned into a deliberate marketing strategy, plays an important role in the competitiveness of a destination.

\section{Conclusion}

The three theoretical foundations of strategic management, namely Resource Based View (RBV), Emergent Strategy (ES) and Positioning Strategy (PS), and concepts from the field of gastronomy, such as gastronomic identity, tourist behaviours (motivation, experience, consumption), a sense of place, and food image were all employed to explain the strategic role of gastronomy destinations. According to the suggested model, which consists of three main components (the source, process and form of a strategy), gastronomic identity is considered a strategic resource for destinations. Depending on the gastronomic identity, a differentiation strategy can be formed in a destination that involves the presentation of gastronomic products developed and offered by discoverers to the relevant markets. This strategy is the result of an emergent, rather than deliberate, strategic process. However, when destination managers or stakeholders see that a gastronomy-based strategy has emerged, such a strategy can also be transformed into a deliberate strategy.

The proposed model, based on an extensive literature review, provides a conceptual framework for understanding the strategic role of gastronomy in destinations, whilst also helping to develop some suggestions for destination managers. These proposals can be thought of in terms of two main axes; enabling the emergence of strategies and turning emerging strategies into deliberate strategies.

First, for a strategy to emerge, the cultural and geographical factors that make a gastronomic identity unique must be well understood by destination stakeholders. The way to do this is through research and training. At the same time, it is important to imagine possible gastronomic tourism products that might be developed based on a gastronomic identity. It may be useful, therefore, to enable those with ideas for new gastronomic tourism products to develop them, including through providing financial support if necessary. For the strategy to become deliberate, it is necessary to establish and protect quality standards by ensuring that stakeholders are organized and cooperative. An effective management organization should therefore be considered, to focus on marketing efforts and take an active role in evaluating the outcomes of the process. 
Although there is a significant body of literature on the relationship between gastronomy and tourism (Rand et al., 2003; Hjalager, 2004; Kivela \& Crotts, 2006; Hall \& Mitchell, 2007; Karim \& Chi, 2010; Chaney \& Ryan, 2012; Leng \& Badarulzaman, 2014; Jiménez Beltrán et al., 2016; Jiménez Beltrán et al., 2016; Chang \& Mak, 2018; Agyeiwaah et al., 2019; Widjaja et al., 2020), there is not much dealt with the question of what is the strategic role of gastronomy in tourism destinations. Especially the study which has benefited three strategic approaches (resource-based view, emergent strategy and positioning strategy) to investigate the strategic use of gastronomy in destination remains underexplored in the literature. The proposed model in this study aims to contribute to the literature and fill this gap.

It is necessary to mention some of the limitations of the present study. First, due to its conceptual nature, the present study lacks empirical findings. Related findings, from conceptual and empirical studies in the strategic management and gastronomy literature, have been used to overcome this deficiency. However, further research is required to test the model presented here. The theoretical basis of this study consists of three approaches that belong to the discipline of strategic management, namely the resourcebased approach, emergent strategy, and positioning strategy. Therefore, the model is largely limited to the foundational beliefs of these approaches. In practice, the gastronomy-tourism relationship is sometimes deliberately developed with a planned approach; models based on a strategic planning approach may, therefore, be needed. In this context, the process of creating a gastronomic destination brand value can be considered within the scope of planned marketing strategies. Although it is not mentioned in this study, a clustering approach has become an important theoretical framework for describing destination competitiveness in recent years. Future studies may also investigate the impact of a clustering approach on gastronomy-tourism integration in destinations.

\section{References}

Acedo, F. J., Barroso, C., \& Galan, J. L. (2006). The resource-based theory: dissemination and main trends. Strategic Management Journal, 27(7), 621-636.

Agyeiwaah, E., Otoo, F. E., Suntikul, W., \& Huang, W. J. (2019). Understanding culinary tourist motivation, experience, satisfaction, and loyalty using a structural approach. Journal of Travel \& Tourism Marketing, 36(3), 295-313.

Alonso, A. D. (2010). Olives, hospitality and tourism: a Western Australian perspective. British Food Journal. 112(1), 55-68.

Alonso, A. D. (2017a). An exploration of Cava wineries: a resource-based approach. International Journal of Wine Business Research, 29(1), 20-36.

Alonso, A. D. (2017b). Exploring a developing tourism industry: A resource-based view approach. Tourism Recreation Research, 42(1), 45-58.

Alonso, A. D., \& Bressan, A. (2016). A resource-based view of the firm and micro and small Italian wine firms. International Journal of Wine Business Research. 28(4), 349-368.

Alonso, A. D., \& Kok, S. (2018). A resource-based view and dynamic capabilities approach in the context of a region's international attractiveness: The recent case of Western Australia. Local Economy, 33(3), 307-328.

Alonso, A. D., Kok, S., \& O'Brien, S. (2018). 'We are only scratching the surface'-a resource-based and dynamic capabilities approach in the context of culinary tourism development. Tourism Recreation Research, 43(4), 511-526.

Andersson, T. D., \& Mossberg, L. (2017). Travel for the sake of food. Scandinavian Journal of Hospitality and Tourism, 17(1), 44-58.

Andersson, T. D., Getz, D., Vujicic, S., Robinson, R. N., \& Cavicchi, A. (2016). Preferred travel experiences of foodies: An application of photo elicitation. Journal of Vacation Marketing, 22(1), 5567. 
Andreu, R., Claver, E., \& Quer, D. (2010). Entry of Spanish tourism firms into new businesses. International Journal of Contemporary Hospitality Management. 22(1), 7-23.

Aydin, A. (2019). The Strategic Process of Integrating Gastronomy and Tourism: The Case of Cappodocia. Journal of Culinary Science \& Technology, 1-24.

Balderas-Cejudo, A., Patterson, I., \& Leeson, G. W. (2019). Senior Foodies: A developing niche market in gastronomic tourism. International Journal of Gastronomy and Food Science, 16, 100152.

Barney, J. (1991). Firm resources and sustained competitive advantage. Journal of management, 17(1), 99120.

Barney, J. B. (2001). Resource-based theories of competitive advantage: A ten-year retrospective on the resource-based view. Journal of management, 27(6), 643-650.

Barney, J. B. (2002). Strategic management: From informed conversation to academic discipline. Academy of Management Perspectives, 16(2), 53-57.

Barney, J. B., \& W. S. Hesterley, (2006). Strategic management and competitive advantage - concepts. Upper Saddle River, NJ: Pearson Prentice Hall.

Barney, J., Wright, M., \& Ketchen Jr, D. J. (2001). The resource-based view of the firm: Ten years after 1991. Journal of management, 27(6), 625-641.

Beer, S., Edwards, J., Fernandes, C., \& Sampaio, F. (2002). Regional Food Cultures: Integral to the Rural Tourism Product?. In A. M. Hjalager ve G. Richards (Ed.). Tourism and Gastronomy (205-223). London: Routledge.

Björk, P., \& Kauppinen-Räisänen, H. (2014). Culinary-gastronomic tourism-A search for local food experiences. Nutrition \& Food Science, 44(4), 294-309.

Bodwell, W., \& Chermack, T. J. (2010). Organizational ambidexterity: Integrating deliberate and emergent strategy with scenario planning. Technological Forecasting and Social Change, 77(2), 193-202.

Botha, C., Crompton, J. L., \& Kim, S. (1999). Developing a revised competitive position for Sun/Lost City, South Africa. Journal of Travel Research, 37, 341-352.

Bourlakis, M. A., \& Bourlakis, C. A. (2001). Deliberate and emergent logistics strategies in food retailing: a case study of the Greek multiple food retail sector. Supply Chain Management: An International Journal. 6(4), 189-200.

Boyne, S., Hall, D., \& Williams, F. (2003). Policy, support and promotion for food-related tourism initiatives: A marketing approach to regional development. Journal of Travel \& Tourism Marketing, 14(3-4), 131-154.

Chandralal, L., \& Valenzuela, F. R. (2013). Exploring memorable tourism experiences: Antecedents and behavioural outcomes. Journal of Economics, Business and Management, 1(2), 177-181.

Chaney, S., \& Ryan, C. (2012). Analyzing the evolution of Singapore's World Gourmet Summit: An example of gastronomic tourism. International journal of hospitality management, 31(2), 309-318.

Chang, R. C., \& Mak, A. H. (2018). Understanding gastronomic image from tourists' perspective: A repertory grid approach. Tourism Management, 68, 89-100.

Chen, J. S., \& Uysal, M. (2002). Market positioning analysis: A hybrid approach. Annals of tourism research, 29(4), 987-1003.

Chi, C. G. Q., Chua, B. L., Othman, M., \& Karim, S. A. (2013). Investigating the structural relationships between food image, food satisfaction, culinary quality, and behavioral intentions: The case of Malaysia. International Journal of Hospitality \& Tourism Administration, 14(2), 99-120.

Claveria, O., \& Poluzzi, A. (2017). Positioning and clustering of the world's top tourist destinations by means of dimensionality reduction techniques for categorical data. Journal of Destination Marketing \& Management, 6, 22-32.

Coudounaris, D. N., \& Sthapit, E. (2017). Antecedents of memorable tourism experience related to behavioral intentions. Psychology \& Marketing, 34(12), 1084-1093. 
Crompton, J. L., Fakeye, P. C., \& Lue, C. (1992). Positioning: The example of the Lower Rio Grande Valley in the winter long stay destination market. Journal of Travel Research, 31, 20-26.

De Carlo, M., \& Dubini, P. (2010). Integrating heritage management and tourism at Italian cultural destinations. International Journal of Arts Management, 30-43.

Downs, A., Durant, R., \& Carr, A. N. (2003). Emergent strategy development for organizations. Emergence, 5(2), 5-28.

Evans, N. G. (2016). Sustainable competitive advantage in tourism organizations: A strategic model applying service dominant logic and tourism's defining characteristics. Tourism Management Perspectives, 18, 14-25.

Evren, S., \& Kozak, N. (2018). Competitive positioning of winter tourism destinations: A comparative analysis of demand and supply sides perspectives-Cases from Turkey. Journal of Destination Marketing \& Management, 9, 247-257.

Fields, K. (2002). Demand for the gastronomy tourism product: Motivational factors. In A.-M. Hjalager \& G. Richards (Eds.), Tourism and gastronomy (pp. 36-50). London: Routledge.

Fox, R. (2007). Reinventing the gastronomic identity of Croatian tourist destinations. International Journal of Hospitality Management, 26(3), 546-559.

Frochot, I. (2003). An Analysis of Regional Positioning and Its Associated Food Images in French Tourism Regional Brochures. Journal of Travel \& Tourism Marketing. 14 (3-4). 77-96.

Gallarza, M. G., Gil, I., \& Garcia, H. C. (2002). Destination image: Toward a conceptual framework. Annals of Tourism Research, 29(1), 56-78.

Gao, Y., \& Hafsi, T. (2018). Does charitable giving substitute or complement firm differentiation strategy? Evidence from Chinese private SMEs. European Management Review.

Gianezini, M., Alves, A.B., Techemayer, C.A. and Révillion, J.P.P. (2012), “Diferenciação de produto e inovação na indústria agroalimentar: a inserção de alimentos funcionais no Brasil", "Revista de administração", Contabilidade e Economia, 11(1), 9-26.

Gordin, V., Trabskaya, J., \& Zelenskaya, E. (2016). The role of hotel restaurants in gastronomic place branding. International Journal of Culture, Tourism and Hospitality Research. 10(1), 81-90.

Grant, R. M. (1991). The resource-based theory of competitive advantage: implications for strategy formulation. California management review, 33(3), 114-135.

Hall, C. M., \& Mitchell, R. (2007). Gastronomic tourism: Comparing food and wine tourism experiences. In Niche tourism (pp. 87-102). Routledge.

Harrington, R. J. (2005). Defining gastronomic identity: The impact of environment and culture on prevailing components, texture and flavors in wine and food. Journal of culinary science \& technology, 4(2-3), 129-152.

Harrington, R. J., \& Ottenbacher, M. C. (2010). Culinary tourism-A case study of the gastronomic capital. Journal of Culinary Science \& Technology, 8(1), 14-32.

Henderson, J.C. (2009). Food tourism reviewed. British Food Journal, 111(4), 317-326.

Hillel, D., Belhassen, Y., \& Shani, A. (2013). What makes a gastronomic destination attractive? Evidence from the Israeli Negev. Tourism Management, 36, 200-209.

Hjalager, A. M. (2002). A typology of gastronomy tourism. In A.M. Hjalager, \& G. Richards (Eds.), Tourism and gastronomy (pp. 21-35), London: Routledge.

Hjalager, A. M., \& Corigliano, M. A. (2000). Food for tourists- Determinants of an image. The International Journal of Tourism Research, 2(4), 281.

Hjalager, A. M., \& Richards, G. (2002). Still Undigested: Research Issues in Tourism and Gastronomy. In A. M. Hjalager \& G. Richards (Eds.), Tourism and Gastronomy (pp. 224-234). London: Routledge.

Hjalager, A.M. (2004). What do tourists eat and why? Towards a sociology of gastronomy and tourism. Tourism (Zagreb), 52(2), 195-201. 
Horng, J. S., \& Tsai, C. T. S. (2010). Government websites for promoting East Asian culinary tourism: A cross-national analysis. Tourism management, 31(1), 74-85.

Horng, J. S., \& Tsai, C. T. S. (2012). Culinary tourism strategic development: an Asia-Pacific perspective. International journal of tourism research, 14(1), 40-55.

Ignatov, E., \& Smith, S. (2006). Segmenting Canadian culinary tourists. Current Issues in Tourism, 9(3), $235-255$.

Jiménez Beltrán, J., López-Guzmán, T., \& Santa-Cruz, F. G. (2016). Gastronomy and tourism: Profile and motivation of international tourism in the city of Córdoba, Spain. Journal of Culinary Science \& Technology, 14(4), 347-362.

Karim, S. A., \& Chi, C. G. Q. (2010). Culinary Tourism as a Destination Attraction: An Empirical Examination of Destinations' Food Image. Journal of Hospitality Marketing \& Management. 19 (6). 531-555.

Kim, J. H., Ritchie, J. B., \& McCormick, B. (2012). Development of a scale to measure memorable tourism experiences. Journal of Travel Research, 51(1), 12-25.

Kim, S. S., Guo, Y., \& Agrusa, J. (2005). Preference and positioning analyses of overseas destinations by mainland Chinese outbound pleasure tourists. Journal of Travel Research, 44(2), 212-220.

Kim, Y. G., Eves, A., \& Scarles, C. (2009). Building a model of local food consumption on trips and holidays: A grounded theory approach. International Journal of Hospitality Management, 28(3), 423431.

Kivela, J., \& Crotts, J. C. (2006). Tourism and gastronomy: Gastronomy's influence on how tourists experience a destination. Journal of Hospitality \& Tourism Research, 30(3), 354-377.

Klinger, C. P., Silveira-Martins, E., de Castro, G. J., \& Rosetto, C. R. (2019). Strategic positioning, differentiation and performance of Brazilian wineries. International Journal of Wine Business Research. Doi: https://doi.org/10.1108/IJWBR-11-2018-0068

Kopmann, J., Kock, A., Killen, C. P., \& Gemünden, H. G. (2017). The role of project portfolio management in fostering both deliberate and emergent strategy. International Journal of Project Management, 35(4), 557-570.

Kumar, G. M. K. (2019). Gastronomic tourism-A way of supplementing tourism in the Andaman \& Nicobar Islands. International Journal of Gastronomy and Food Science, 16, 100139.

Lee, C. F., \& King, B. (2006). Assessing destination competitiveness: An application to the hot springs tourism sector. Tourism and Hospitality Planning \& Development, 3(3), 179-197.

Li, X., Cheng, C. K., Kim, H., \& Li, X. (2015). Positioning USA in the Chinese outbound travel market. Journal of Hospitality \& Tourism Research, 39(1), 75-104.

Lowe, A., \& Jones, A. (2004). Emergent strategy and the measurement of performance: The formulation of performance indicators at the microlevel. Organization Studies, 25(8), 1313-1337.

Mariani, M. M. (2007). Coopetition as an emergent strategy: Empirical evidence from an Italian consortium of opera houses. International Studies of Management \& Organization, 37(2), 97-126.

Mascarenhas, R. G. T., \& Gândara, J. M. G. (2015). The role of gastronomy in the quality and competitiveness on touristic destinations. Cultur: Revista de Cultura e Turismo, 9(1), 60-83.

Massukado-Nakatani, M. S., \& Teixeira, R. M. (2009). Resource-based view as a perspective for public tourism management research: evidence from two Brazilian tourism destinations. BAR-Brazilian Administration Review, 6(1), 62-77.

Maurer, C. C., Bansal, P., \& Crossan, M. M. (2011). Creating economic value through social values: Introducing a culturally informed resource-based view. Organization Science, 22(2), 432-448.

McDermott, C. M., \& O'Connor, G. C. (2002). Managing radical innovation: an overview of emergent strategy issues. Journal of Product Innovation Management: an international publication of the product development \& management association, 19(6), 424-438.

Mintzberg, H. (1978). Patterns in strategy formulation. Management Science, 24, 934-948. 
Mintzberg, H. (1985). “Of Strategies, Deliberate and Emergent”. Strategic Management Journal, 6: 257 272.

Mirabeau, L., \& Maguire, S. (2014). From autonomous strategic behavior to emergent strategy. Strategic Management Journal, 35(8), 1202-1229.

Morgan, M., \& Xu, F. (2009). Student travel experiences: Memories and dreams. Journal of Hospitality Marketing \& Management, 18(2-3).

Nebioğlu, O. (2016). "Yerel Gastronomik Ürünlerin Turizmde Kullanılmasini Etkileyen Faktörler". Akdeniz University, Institute of Social Sciences, Tourism and Hotel Management, Unpublished PhD Thesis.

Neugebauer, F., Figge, F., \& Hahn, T. (2016). Planned or emergent strategy making? Exploring the formation of corporate sustainability strategies. Business strategy and the environment, 25(5), 323336.

Oh, H., Fiore, A. M., \& Jeoung, M. (2007). Measuring experience economy concepts: Tourism applications. Journal of travel research, 46(2), 119-132.

Okumus, B., Okumus, F., \& McKercher, B. (2007). Incorporating local and international cuisines in the marketing of tourism destinations: The cases of Hong Kong and Turkey. Tourism Management, 28(1), 253-261.

Okumus, F., Kock, G., Scantlebury, M. G., \& Okumus, B. (2013). Using Local Cuisines when Promoting Small Caribbean Island Destinations. Journal of Travel \& Tourism Marketing, 30 (4). 410-429.

Ottenbacher, M. C., \& Harrington, R. J. (2013). A case study of a culinary tourism campaign in Germany: Implications for strategy making and successful implementation. Journal of Hospitality \& Tourism Research, 37(1), 3-28.

Özdemir, B., \& Seyitoğlu, F. (2017). A conceptual study of gastronomical quests of tourists: Authenticity or safety and comfort?. Tourism Management Perspectives, 23, 1-7.

Peteraf, M. A. (1993). The cornerstones of competitive advantage: a resource-based view. Strategic management journal, 14(3), 179-191.

Peters, M., Siller, L., \& Matzler, K. (2011). The resource-based and the market-based approaches to cultural tourism in alpine destinations. Journal of Sustainable Tourism, 19(7), 877-893.

Porter, M. E., (1980). Competitive Strategy Techniques for Analyzing Industries and Competitors, Free Press, New York.

Porter, M. E., (1985). Competitive advantage. New York: Free Press.

Quan, S., \& Wang, N. (2004). Towards a structural model of the tourist experience: An illustration from food experiences in tourism. Tourism management, 25(3), 297-305.

Rand, G. E. D., Heath, E., \& Alberts, N. (2003). The role of local and regional food in destination marketing: A South African situation analysis. Journal of Travel \& Tourism Marketing, 14(3-4), 97112.

Rodríguez-Molina, M. A., Frías-Jamilena, D. M., Del Barrio-García, S., \& Castañeda-García, J. A. (2019). Destination brand equity-formation: Positioning by tourism type and message consistency. Journal of Destination Marketing \& Management, 12, 114-124.

Rojas-Mendez, J. I., \& Hine, M. J. (2017). Countries' positioning on personality traits: Analysis of 10 South American national tourism websites. Journal of Vacation Marketing, 23(3), 233-247.

Rusko, R., Merenheimo, P., \& Haanpää, M. (2013). Coopetition, resource-based view and legend: Cases of Christmas tourism and city of Rovaniemi. International Journal of Marketing Studies, 5(6), 3751.

Shenoy, S. (2005). Food tourism and the culinary tourist (Ph.d. thesis). Recreation and Tourism Management at Graduate School of Clemson University, Parks.

Shoemaker, S., Lewis, R. C., \& Yesawich, P. C. (2007). Marketing leadership in hospitality and tourism: Strategies and tactics for competitive advantage. Upper Saddle River, NJ: Pearson Prentice Hall. 
Smith, S. L., \& Xiao, H. (2008). Culinary tourism supply chains: A preliminary examination. Journal of travel research, 46(3), 289-299.

Sthapit, E. (2017). Exploring tourists' memorable food experiences: A study of visitors to Santa's official hometown. Anatolia, 28(3), 404-421.

Suet Leng, K., \& Badarulzaman, N. (2014). Branding George Town world heritage site as city of gastronomy: prospects of creative cities strategy in Penang. International Journal of Culture, Tourism and Hospitality Research, 8(3), 322-332.

Tsai, C. T. S. (2016). Memorable tourist experiences and place attachment when consuming local food. International Journal of Tourism Research, 18(6), 536-548.

Uysal, M., Chen, J. S., \& Williams, D. R. (2000). Increasing state market share through a regional positioning. Tourism Management, 21(1), 89-96.

Uzut, İ. (2016). "Turizm Açısından Stratejik Bir Kaynak Olarak Gastronomik Kimlik: Kaynaklara Dayalı Yaklaşim Modeli Çerçevesinde Bir Araştırma" Akdeniz University, Institute of Social Sciences, Tourism and Hotel Management, Unpublished Master's Thesis.

Vignolles, A., \& Pichon, P. E. (2014). A taste of nostalgia: links between nostalgia and food consumption. Qualitative market research: an international journal, 17(3), 225-238.

Wernerfelt, B. (1995). The resource-based view of the firm: Ten years after. Strategic management journal, 16(3), 171-174.

Widjaja, D. C., Jokom, R., Kristanti, M., \& Wijaya, S. (2020). Tourist behavioural intentions towards gastronomy destination: evidence from international tourists in Indonesia. Anatolia, 1-17.

Wolf, E. (2006). Culinary tourism: The hidden harvest. Dubuque, IA: Kendall/Hunt. 